\title{
DFT Computational Studies on Some Cobaloximes
}

\author{
Ayşin Zülfikaroğlu ${ }^{1^{*}}$ \\ ${ }^{1}$ Department of Chemistry, Faculty of Arts \& Science, Amasya University, 05000, Amasya, Turkey
}

Geliş / Received: 19/11/2020, Kabul / Accepted: 07/12/2020

\begin{abstract}
This study carried out quantum chemical investigations on cobaloxime complexes: $\left[\mathrm{Co}(\mathrm{dpgH})_{2} \mathrm{Cl}\left(\mathrm{H}_{2} \mathrm{O}\right)\right](\mathrm{C} 1)$, $\left[\mathrm{Co}(\mathrm{dpgH})_{2}(\mathrm{Pz}) \mathrm{Cl}\right](\mathrm{C} 2),\left[\mathrm{Co}(\mathrm{dpgH})_{2}(\mathrm{Im}) \mathrm{Cl}\right](\mathrm{C} 3),\left[\mathrm{Co}(\mathrm{dpgH})_{2}(\mathrm{py}) \mathrm{Cl}\right](\mathrm{C} 4)$ and $\left[\mathrm{Co}(\mathrm{dpgH})_{2}\left(\mathrm{CH}_{3}\right)(\mathrm{py}) \mathrm{Cl}\right]$ (C5), where $\mathrm{dpgH}^{-}$is diphenyl glyoximate, $\mathrm{Pz}$ is pyrazine, Im is imidazole and py is pyridine. The stable molecular geometries of these complexes were achieved using Density Functional Theory (DFT). The values of the geometrical parameters obtained from optimized cobaloxime complexes were compatible with experimental data. In order to predict the chemical reactivity of the complexes, their frontier molecular orbital (FMO) energies and their reactivity parameters based on DFT were calculated for optimized cobaloxime complexes. The interaction of the cobaloximes with different DNA bases and Watson-Crick base pairs (A-T and $\mathrm{G}-\mathrm{C}$ ) were explored on the basis of the different reactivity parameters of density functional reactivity theory (DFRT). The results revealed that cobaloximes studied generally acted as an electron-acceptor agent in their interaction with biomolecules. The order of interaction of cobaloximes with all biomolecules followed the sequence $\mathrm{C} 1>\mathrm{C} 2>\mathrm{C} 3>\mathrm{C} 4>\mathrm{C} 5$.
\end{abstract}

Keywords: Cobaloxime, DFT, Stabilization energy, DNA bases

\section{Bazı Kobaloksimler Üzerinde YFT Hesaplamalı Çalışmalar}

$\ddot{\mathbf{O} z}$

$\mathrm{Bu}$ çalışmada, kobaloksim kompleksleri “ $\left[\mathrm{Co}(\operatorname{dpgH})_{2} \mathrm{Cl}\left(\mathrm{H}_{2} \mathrm{O}\right)\right] \quad(\mathrm{C} 1), \quad\left[\mathrm{Co}(\operatorname{dpgH})_{2}(\mathrm{Pz}) \mathrm{Cl}\right] \quad(\mathrm{C} 2)$, $\left[\mathrm{Co}(\mathrm{dpgH})_{2}(\mathrm{Im}) \mathrm{Cl}\right] \quad(\mathrm{C} 3), \quad\left[\mathrm{Co}(\mathrm{dpgH})_{2}(\mathrm{py}) \mathrm{Cl}\right] \quad(\mathrm{C} 4) \quad$ ve $\left[\mathrm{Co}(\mathrm{dpgH})_{2} \quad\left(\mathrm{CH}_{3}\right)(\mathrm{py}) \mathrm{Cl}\right] \quad(\mathrm{C} 5), \quad \mathrm{dpgH}^{-}=$ difenilglioksim, $\mathrm{Pz}=$ pirazin, $\mathrm{Im}=$ imidazol and $\mathrm{Py}=$ Piridin" üzerine kuantum kimyasal araştırmalar yapılmıştır. Komplekslerin kararlı moleküler geometrileri, Yoğunluk Fonksiyonel Teorisi (YFT) yöntemleri kullanılarak elde edilmiştir. Optimize edilmiş kobaloksim komplekslerinden elde edilen geometrik parametre değerlerinin deneysel verilerle uyumlu olduğu görülmüştür. Komplekslerin kimyasal reaktivitesini tahmin etmek için, sınır moleküler orbital (SMO) enerjileri ve YFT'ye dayalı reaktivite parametreleri, optimize edilmiş kobaloksim kompleksleri için hesaplanmıştır. Kobaloksimlerin farklı DNA bazları ve Watson - Crick baz çiftleri (A - T ve G - C) ile etkileşimi, yoğunluk fonksiyonel reaktivite teorisinin (DFRT) farklı reaktivite parametreleri ile araştırılmıştır. Sonuçlar, incelenen kobaloksimlerin biyomoleküllerle etkileşimlerinde genellikle bir elektron-alıcı olarak davrandığını göstermiştir. Kobaloksimlerin tüm biyomoleküller ile etkileşim sırasının $\mathrm{C} 1>\mathrm{C} 2>\mathrm{C} 3>\mathrm{C} 4>\mathrm{C} 5$ şeklinde olduğu belirlenmiştir.

Anahtar Kelimeler: Kobaloksim, YFT, Stabilizasyon enerjisi, DNA bazları

\section{Introduction}

Cobaloximes, first discovered by Tschugaef in 1907, represent a unique class of compounds in organo metallic and bioinorganic chemistry (Gupta et al.,2006). These complexes, which are the dioxime complexes of cobalt(III) (both organic and inorganic) have the general formula $\mathrm{RCo}(\mathrm{L})_{2} \mathrm{~B}$, where $\mathrm{L}$ is the dioxime ligand - 
such as dimethylglyoxime ( $\mathrm{dmgH})$, glyoxime $(\mathrm{gH})$ and diphenylglyoxime $(\mathrm{dpgH})$ at the equatorial position - and the axial ligands $\mathrm{R}$ and $\mathrm{B}$ are an organic or inorganic group (Bhuyan et al., 2008; Kumar et al., 2010). The common feature of these complexes is that each possesses a strong equatorial ligand field (Meera et al., 2011). The diversity and properties of cobaloximes generally depend on the type of ligands axially coordinated with the cobalt(III) ion (Coropceanua et al., 2012). These compounds have been of great interest to chemists due to their rich coordination chemistry, stability, redox properties and potential applications in organic synthesis (Gupta et al., 2006; Coropceanua et al., 2017; Kumar and Gupta, 2010; Mandal and Gupta, 2006). In particular, $\mathrm{Co}(\mathrm{dmgH})_{2}(\mathrm{py}) \mathrm{Cl}$ - where $\mathrm{dmgH}$ is dimethylglyoximate and py is pyridine has been widely used as a catalyst for high efficiency hydrogen production in an aqueous environment (Chen and Sit, 2018; $\mathrm{Xu}$ et al., 2017; Ye et al., 2016; Gao et al., 2016; Natali, 2017; McCormick et al., 2011). Cobaloximes also have useful properties in biological systems. They have extensively been used as structural and functional mimics for vitamin B12 since they were proposed by Schrauzer as models for the B12 coenzyme (Kumar and Gupta, 2010; Bourosh et al., 2013).

The design and development of nextgeneration metal-containing drugs has been an emerging field of research for nearly the past fifty years. The success of metalcontaining anti-cancer agents in cancer treatment further increases the interest in these compounds (Sarmah and Roy, 2013). It is important to understand the interaction mechanism of the drug agent with DNA bases, which is the molecular target for many anticancer drugs, and to know the physical and chemical properties of these compounds for the design of more effective drugs (Sarmah and Roy, 2013).

Density functional reactivity theory is a powerful tool in studying the properties of molecules and interactions between two drug-target species (Sarmah and Roy, 2013; Sarmah and Roy, 2014). It can be also used to predict, analyze and interpret the outcome of chemical reactions (Bagaria et al., 2009; Saha et al., 2019; Hamid and Roy, 2020 Hamid and Roy, 2020; Frau et al., 2017). In previous theoretical studies on some cobaloximes, their molecular properties (Kumar et al., 2010) and hydrogen-producing mechanisms (Solis and Hammes-Schiffer, 2011; Bhattacharjee and Andreiadis, 2013; Muckerman and Fujita, 2011; Solis et al., 2013; Jiang and Liu, 2012) were investigated using DFRT. In this study, computational research was carried out on five cobaloxime complexes whose structures are given in Figure 1 (Lopez et al., 1987; Lopez et al., 1991; Mandal and Gupta 2006; Meera et al., 2009; Meera et al., 2011). X-ray structural analysis results for these complexes with octahedral geometry are available in published literature, but a thorough quantum chemical description is lacking. Inspection of the molecular structures was carried out using DFT with two hybrid functionals. The highest occupied molecular orbitals (HOMOs) and the lowest unoccupied molecular orbitals (LUMOs) were obtained using the DFT. The chemical reactivity parameters of all complexes were calculated, and their interactions with DNA bases and base pairs were investigated using stabilization energy and the components of the reactivity descriptors within the framework of DFRT. This study is valuable in providing insight into the molecular properties of cobaloxime complexes and it sheds light on developing studies of cobaloxime complexes as a drug agent. 


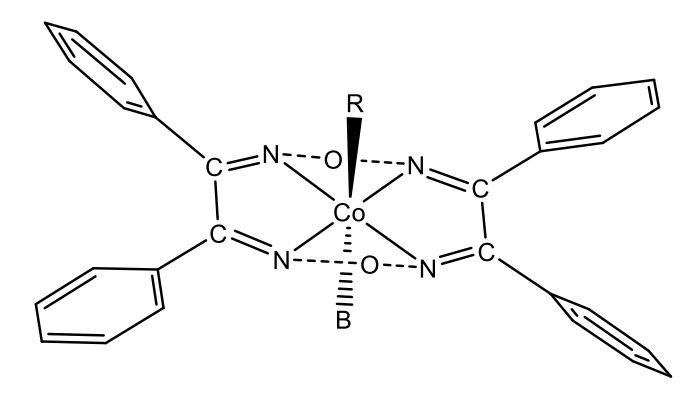



Figure 1. The structures of the

complexes studied

\section{2- Computational Details}

All theoretical calculations were carried out using the Gaussian 09 software package (Frisch et al., 2017) The geometry of cobaloxime complexes ( $\mathrm{C} 1$ to $\mathrm{C} 5$ ) were optimized using DFT. In these calculations, the two hybrid functionals B3LYP (Becke 3parameter exchange functional along with the correlation functional, as proposed by Lee, Yang and Parr) (Becke, 1992; Becke 1993; Lee, 1988) and mPW1PW91 which is classified to Hybrid Hartree-Fock density functional theory (Hybrid-DFT) which combines the exchange-correlation of a percentage of Hartree-Fock (or exact) exchange (Krishnan et al., 1980; Adamo and
Barone, 1998; Lynch etal, 2000; Zhao et al., 2005; Yang and Gao, 2012), were employed with the $6-311 \mathrm{G}(\mathrm{d}, \mathrm{p})$ basis set for all nonmetallic atoms and the combined pseudopotential-based basis set LanL2DZ (T.H. Dunning and P.J. Hay, 1976) for the cobalt atom. The harmonic vibrational frequencies were calculated at the same levels of theory to make sure that the stationary points were minimized. The HOMO-LUMO energy was calculated at the ground state and the same theoretical level. The Chemissian program (Skripnikov, 2016) was used to visualize the frontier molecular orbital surfaces and to calculate the fractional contributions of various groups to each molecular orbit for all of the complexes. Density functional theory was used to define the molecular properties, such as chemical potential $(\mu)$, chemical hardness $(\eta)$, softness $(S)$, electronegativity $(\chi)$ and electrophilicity index $(\omega)$. The electron transfer $(\Delta \mathrm{N})$, stabilization energy $\left(\Delta E_{S E(A B)}\right)$ and its different components, such as the energy raising component $\left(\Delta E_{B(A)}\right)$ and the energy lowering component $\left(\Delta E_{A(B)}\right)$ were used to study the interaction of cobaloxime complexes with nucleic acid bases (adenine, guanine, cytosine, thymine and uracil) and Watson-Crick base pairs (A-T and $\mathrm{G}-\mathrm{C}$ ). The structures of all biomolecules were prepared using the the GaussView 5.0.8 program (Dennington et al., 2009) and were optimized at the B3LYP/6-311G(d,p) level of theory. Subsequent single-point calculations were performed at the same level of theory.

\section{3- Result and Discussion}

\subsection{Optimized Structure}

DFT calculations were performed on the five cobaloxime complexes with the B3LYP and mPW1PW91 methods. The calculated parameters are shown in Table 1with the 
corresponding experimental values. The optimized structures of these complexes are shown in Figure 2. In order to compare the geometric parameters computed with experimental values, the root mean square error (RMSE) (Table 1) was used. The calculated RMSE values for bond lengths were in the range from 0.02376 to 0.04685 for B3LYP, and 0.01247 to 0.029338 for mPW1PW91. The RMSE values for bond angles were calculated to be in the range from 1.00361 to $2.30126^{\circ}$ for B3LYP, and 1.02944 to $2.11635^{\circ}$ for mPW1PW91. To make a comparison with the experimental results, the regression values $\left(\mathrm{R}^{2}\right)$ were also obtained from the correlation between the calculated bond parameters and the experimental bond parameters corresponding to the methods of calculation. As seen in Table S1, the correlations were linear, and $\mathrm{R}^{2}$ values were in the range from 0.997 to 0.994 for both methods. All results showed that the bond parameters calculated with the B3LYP and mPW1PW91 methods were in generally good agreement with the XRD values, but the mPW1PW91 method results agreed slightly better with the experimental results compared to the B3LYP method results. All calculated $\mathrm{Co}-\mathrm{N}_{\text {oxime }}$ bond lengths in the five complexes were similar to each other. In $\mathrm{C} 4$ and $\mathrm{C} 5$, the lengths of $\mathrm{Co}-\mathrm{N}_{\mathrm{py}}$ bonds in axial position were about $2 \AA$, and these bonds were slightly longer than the $\mathrm{Co}-\mathrm{N}_{\text {oxime }}$ bonds in the equatorial position. The $\mathrm{Co}-\mathrm{Cl}$ distances in the $\mathrm{C} 1$ to $\mathrm{C} 4$ complexes were almost equal to each other. The $\mathrm{Cl}-\mathrm{Co}-\mathrm{N}_{\text {oxime }}$ angles were smaller than $90^{\circ}$ (the usual angle seen for an octahedral complex), except for complex 1, while the $\mathrm{N}_{\text {axi }}-\mathrm{Co}-\mathrm{N}_{\text {oxime }}$ angles were larger than $90^{\circ}$. Not all the complexes had the complete octahedral geometry.

\subsection{Frontier molecular orbitals analysis}

Frontier molecular orbitals (FMOs) are an important notion in quantum chemistry and give information about molecular structures (Khan et al., 2020). Two important molecular orbitals, the highest occupied molecular orbital (HOMO) and the lowest unoccupied molecular orbital (LUMO) are fundamental standard quantum parameters (Kurnaz et al., 2016; El- Gammal et al., 2019). Е Номо, $E_{L U M O}$ and $\triangle E_{\text {gap }}\left(E_{L U M O}-E_{\text {HOMO }}\right)$ energy parameters are used to characterize the chemical reactivity and kinetic stability of molecules (Lee et al., 1988; Choudhary et al., 2019). For all of the cobaloxime complexes, the molecular orbital energy levels, HOMO and LUMO surfaces and energy gaps, and percentage contributions of functional groups to these energy levels calculated in the gaseous phase, are shown in Figure 4. The positive and negative phase is represented in green and orange in the HOMO-LUMO orbital diagrams of the complexes, respectively.

Table 1. Selected bond lengths $(\AA)$ and angles $\left(^{\circ}\right)$ for $\mathrm{Co}(\mathrm{III})$ complexes

\begin{tabular}{|c|c|c|c|c|c|c|c|c|}
\hline & Bonds $(\AA)$ & Experimental & B3LYP & mPW1PW91 & Angles $\left(^{\circ}\right)$ & Experimental & B3LYP & mPW1PW91 \\
\hline$x$ & $\mathrm{~N} 1-\mathrm{Co} 1$ & $1.894(3)$ & 1.96326 & 1.93569 & $\mathrm{~N} 1-\mathrm{Co} 1-\mathrm{N} 2$ & $81.13(14)$ & 79.43406 & 80.23586 \\
\hline 날 & $\mathrm{N} 1{ }^{\mathrm{i}}-\mathrm{Co} 1$ & $1.894(3)$ & 1.89559 & 1.88033 & $\mathrm{~N} 1^{\mathrm{i}}-\mathrm{Co} 1-\mathrm{N} 2^{\mathrm{i}}$ & $81.13(14)$ & 82.76005 & 82.99457 \\
\hline है & $\mathrm{N} 2-\mathrm{Co} 1$ & $1.891(3)$ & 1.96332 & 1.93542 & $\mathrm{~N} 1-\mathrm{Co} 1-\mathrm{N} 2^{\mathrm{i}}$ & $98.87(14)$ & 98.48601 & 97.95478 \\
\hline 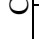 & $\mathrm{N} 2{ }^{\mathrm{i}}-\mathrm{Co} 1$ & $1.891(3)$ & 1.91139 & 1.89550 & $\mathrm{~N} 1{ }^{\mathrm{i}}-\mathrm{Co} 1-\mathrm{N} 2$ & $98.87(14)$ & 99.33975 & 98.84870 \\
\hline
\end{tabular}




\begin{tabular}{|c|c|c|c|c|c|c|c|c|}
\hline & $\mathrm{Cl} 1-\mathrm{Co} 1$ & $2.214(11)$ & 2.25211 & 2.22090 & $\mathrm{Cl} 1-\mathrm{Co} 1-\mathrm{N} 1$ & $90.6(3)$ & 90.30379 & 90.18074 \\
\hline & $\mathrm{O} 3-\mathrm{Co} 1$ & $1.95(3)$ & 2.04649 & 2.01540 & $\mathrm{C} 11-\mathrm{Co} 1-\mathrm{N} 2$ & $86.6(3)$ & 89.92269 & 89.76427 \\
\hline & $\mathrm{C} 1-\mathrm{N} 1$ & $1.298(6)$ & 1.29617 & 1.29223 & $\mathrm{O} 3-\mathrm{Co} 1-\mathrm{N} 1$ & $89.6(9)$ & 92.64147 & 92.56329 \\
\hline & $\mathrm{C} 11^{\mathrm{i}}-\mathrm{N} 1$ & $1.298(6)$ & 1.31066 & 1.30462 & $\mathrm{O} 3-\mathrm{Co} 1-\mathrm{N} 2$ & $91.3(7)$ & 87.50950 & 88.02604 \\
\hline & $\mathrm{C} 2-\mathrm{N} 2$ & $1.294(5)$ & 1.29552 & 1.29148 & $\mathrm{~N} 1-\mathrm{Co} 1-\mathrm{N} 1^{\mathrm{i}}$ & $180.00(17)$ & 177.21687 & 177.98326 \\
\hline & $\mathrm{C} 22^{\mathrm{i}}-\mathrm{N} 1$ & $1.294(5)$ & 1.31793 & 1.31075 & $\mathrm{~N} 2-\mathrm{Co} 1-\mathrm{N} 2^{\mathrm{i}}$ & $179.998(1)$ & 177.86155 & 177.56493 \\
\hline & $\begin{array}{r}R^{2} \\
R M S E\end{array}$ & & $\begin{array}{r}0.99322 \\
0.046847\end{array}$ & $\begin{array}{r}0.99506 \\
0.029338\end{array}$ & $\begin{array}{r}R^{2} \\
R M S E\end{array}$ & & $\begin{array}{r}0.99597 \\
2.301262\end{array}$ & $\begin{array}{r}0.99684 \\
2.116354\end{array}$ \\
\hline \multirow{11}{*}{ 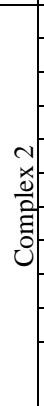 } & $\mathrm{N} 1-\mathrm{Co} 1$ & $1.879(2)$ & 1.96317 & 1.90911 & $\mathrm{~N} 1-\mathrm{Co} 1-\mathrm{N} 2$ & $80.75(12)$ & 82.96179 & 81.54668 \\
\hline & $\mathrm{N} 2-\mathrm{Co} 1$ & $1.888(2)$ & 1.95701 & 1.91308 & $\mathrm{~N} 3-\mathrm{Co} 1-\mathrm{N} 4$ & $81.89(12)$ & 79.39193 & 81.54661 \\
\hline & $\mathrm{N} 3-\mathrm{Co} 1$ & $1.903(2)$ & 1.90065 & 1.90913 & $\mathrm{~N} 2-\mathrm{Co} 1-\mathrm{N} 3$ & $99.05(12)$ & 98.65633 & 98.43617 \\
\hline & $\mathrm{N} 4-\mathrm{Co} 1$ & $1.885(2)$ & 1.89698 & 1.91310 & $\mathrm{~N} 1-\mathrm{Co} 1-\mathrm{N} 4$ & $98.30(12)$ & 98.95390 & 98.43511 \\
\hline & $\mathrm{Cl} 1-\mathrm{Co} 1$ & $2.2244(9)$ & 2.27243 & 2.23787 & $\mathrm{Cl} 1-\mathrm{Co} 1-\mathrm{N} 1$ & $90.96(9)$ & 89.01151 & 88.98414 \\
\hline & N5-Co1 & $1.924(2)$ & 2.00957 & 1.97547 & $\mathrm{Cl} 1-\mathrm{Co} 1-\mathrm{N} 4$ & $89.00(9)$ & 89.29945 & 89.50517 \\
\hline & $\mathrm{C} 1-\mathrm{N} 1$ & $1.296(4)$ & 1.29684 & 1.29365 & $\mathrm{~N} 5-\mathrm{Co} 1-\mathrm{N} 1$ & $91.29(12)$ & 91.42702 & 91.01534 \\
\hline & $\mathrm{C} 2-\mathrm{N} 2$ & $1.296(3)$ & 1.29689 & 1.30810 & N5-Co1-N4 & $91.46(12)$ & 90.09639 & 90.49491 \\
\hline & $\mathrm{C} 15-\mathrm{N} 3$ & $1.291(3)$ & 1.31114 & 1.29365 & $\mathrm{~N} 1-\mathrm{Co} 1-\mathrm{N} 3$ & $179.76(14)$ & 177.79409 & 177.97078 \\
\hline & $\mathrm{C} 16-\mathrm{N} 4$ & $1.291(3)$ & 1.31058 & 1.30810 & $\mathrm{~N} 2-\mathrm{Co} 1-\mathrm{N} 4$ & $177.97(12)$ & 177.47512 & 179.01040 \\
\hline & $\begin{array}{r}R^{2} \\
R M S E \\
\end{array}$ & 0.99862 & $\begin{array}{r}0.9925 \\
0.02376 \\
\end{array}$ & $\begin{array}{r}0.99854 \\
0.02376 \\
\end{array}$ & $\begin{array}{r}R^{2} \\
R M S E \\
\end{array}$ & & $\begin{array}{r}0.99822 \\
1.469324 \\
\end{array}$ & $\begin{array}{r}0.9991 \\
1.029439 \\
\end{array}$ \\
\hline \multirow{11}{*}{ 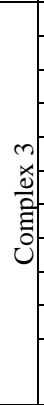 } & $\mathrm{N} 1-\mathrm{Co} 1$ & $1.879(2)$ & 1.89728 & 1.88112 & $\mathrm{~N} 1-\mathrm{Co} 1-\mathrm{N} 2$ & $81.39(10)$ & 82.97227 & 83.16145 \\
\hline & $\mathrm{N} 2-\mathrm{Co} 1$ & $1.888(2)$ & 1.90198 & 1.88529 & N3-Co1-N4 & $80.33(10)$ & 79.57808 & 80.47402 \\
\hline & $\mathrm{N} 3-\mathrm{Co} 1$ & $1.903(2)$ & 1.95286 & 1.92447 & $\mathrm{~N} 2-\mathrm{Co} 1-\mathrm{N} 4$ & $99.27(10)$ & 98.79908 & 98.09437 \\
\hline & N4-Co1 & $1.885(2)$ & 1.96016 & 1.92976 & $\mathrm{~N} 1-\mathrm{Co} 1-\mathrm{N} 3$ & $99.02(10)$ & 98.64010 & 98.25890 \\
\hline & $\mathrm{Cl} 1-\mathrm{Co} 1$ & $2.2244(9)$ & 2.27490 & 2.24129 & $\mathrm{Cl} 1-\mathrm{Co} 1-\mathrm{N} 1$ & $90.47(8)$ & 89.86366 & 89.79819 \\
\hline & N5-Co1 & $1.924(2)$ & 1.97853 & 1.94624 & $\mathrm{Cl} 1-\mathrm{Co} 1-\mathrm{N} 3$ & $90.97(8)$ & 89.26961 & 89.27710 \\
\hline & $\mathrm{C} 1-\mathrm{N} 1$ & $1.296(4)$ & 1.31042 & 1.30333 & $\mathrm{~N} 5-\mathrm{Co} 1-\mathrm{N} 1$ & $89.71(11)$ & 89.69503 & 89.58661 \\
\hline & $\mathrm{C} 2-\mathrm{N} 2$ & $1.296(3)$ & 1.31849 & 1.30387 & $\mathrm{~N} 5-\mathrm{Co} 1-\mathrm{N} 3$ & $89.86(10)$ & 91.17477 & 91.22827 \\
\hline & $\mathrm{C} 15-\mathrm{N} 3$ & $1.291(3)$ & 1.29663 & 1.29307 & $\mathrm{~N} 1-\mathrm{Co} 1-\mathrm{N} 4$ & $179.23(11)$ & 177.96237 & 178.46683 \\
\hline & $\mathrm{C} 16-\mathrm{N} 4$ & $1.291(3)$ & 1.29669 & 1.29328 & $\mathrm{~N} 2-\mathrm{Co} 1-\mathrm{N} 3$ & $178.07(10)$ & 178.27656 & 178.39661 \\
\hline & $\begin{array}{r}R^{2} \\
R M S E\end{array}$ & & $\begin{array}{r}0.99708 \\
0.038686 \\
\end{array}$ & $\begin{array}{r}0.99841 \\
0.018388 \\
\end{array}$ & $\begin{array}{r}R^{2} \\
R M S E\end{array}$ & & $\begin{array}{r}0.99913 \\
1.003615 \\
\end{array}$ & $\begin{array}{r}0.9993 \\
1.049471 \\
\end{array}$ \\
\hline \multirow{11}{*}{ 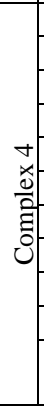 } & N11-Co & $1.911(5)$ & 1.93954 & 1.91386 & $\mathrm{~N} 11-\mathrm{Co}-\mathrm{N} 12$ & $81.4(2)$ & 81.04872 & 81.59097 \\
\hline & $\mathrm{N} 12-\mathrm{Co}$ & $1.903(5)$ & 1.92236 & 1.90858 & $\mathrm{~N} 21-\mathrm{Co}-\mathrm{N} 22$ & $81.6(2)$ & 81.11868 & 81.52983 \\
\hline & $\mathrm{N} 21-\mathrm{Co}$ & $1.904(5)$ & 1.93651 & 1.91666 & $\mathrm{~N} 1-\mathrm{Co}-\mathrm{Cl}$ & $178.2(1)$ & 179.86831 & 179.89289 \\
\hline & $\mathrm{N} 22-\mathrm{Co}$ & $1.900(6)$ & 1.92833 & 1.90249 & $\mathrm{~N} 11-\mathrm{Co}-\mathrm{Cl}$ & $89.4(1)$ & 89.76446 & 89.45032 \\
\hline & $\mathrm{Cl}-\mathrm{Co}$ & $2.235(2)$ & 2.27503 & 2.24212 & $\mathrm{~N} 12-\mathrm{Co}-\mathrm{Cl}$ & $88.7(1)$ & 88.79770 & 88.91503 \\
\hline & $\mathrm{N} 1-\mathrm{Co}$ & $1.965(3)$ & 2.01160 & 1.97568 & $\mathrm{~N} 21-\mathrm{Co}-\mathrm{Cl}$ & 91.1(1) & 89.51767 & 89.66303 \\
\hline & $\mathrm{C} 11-\mathrm{N} 11$ & $1.295(8)$ & 1.31548 & 1.30827 & $\mathrm{~N} 22-\mathrm{Co}-\mathrm{Cl}$ & $90.6(1)$ & 88.93457 & 88.81419 \\
\hline & $\mathrm{C} 12-\mathrm{N} 12$ & $1.296(8)$ & 1.29752 & 1.29343 & $\mathrm{~N} 11-\mathrm{Co}-\mathrm{N} 1$ & $89.3(2)$ & 90.34314 & 90.47095 \\
\hline & $\mathrm{C} 21-\mathrm{N} 21$ & $1.291(9)$ & 1.31516 & 1.30868 & $\mathrm{~N} 12-\mathrm{Co}-\mathrm{N} 1$ & $89.9(2)$ & 91.29404 & 91.00162 \\
\hline & $\mathrm{C} 22-\mathrm{N} 22$ & $1.319(9)$ & 1.29833 & 1.29273 & $\mathrm{~N} 21-\mathrm{Co}-\mathrm{N} 1$ & $90.2(2)$ & 90.37473 & 90.41572 \\
\hline & $\begin{array}{r}R^{2} \\
R M S E \\
\end{array}$ & & $\begin{array}{r}0.99830 \\
0.028732 \\
\end{array}$ & $\begin{array}{r}0.99861 \\
0.012474 \\
\end{array}$ & $\begin{array}{r}R^{2} \\
R M S E\end{array}$ & & $\begin{array}{r}0.99855 \\
1.041214 \\
\end{array}$ & $\begin{array}{r}0.99871 \\
1.041214 \\
\end{array}$ \\
\hline \multirow{11}{*}{ 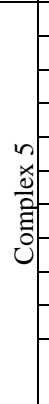 } & $\mathrm{N} 1-\mathrm{Co}$ & $1.884(3)$ & 1.92036 & 1.89804 & $\mathrm{~N} 1-\mathrm{Co}-\mathrm{N} 5$ & $80.8(1)$ & 81.13720 & 81.57360 \\
\hline & $\mathrm{N} 1{ }^{\prime}-\mathrm{Co}$ & $1.884(3)$ & 1.91804 & 1.89956 & $\mathrm{~N} 1^{\prime}-\mathrm{Co}-\mathrm{N} 5^{\prime}$ & $80.8(1)$ & 81.13332 & 81.58960 \\
\hline & N5-Co & $1.883(2)$ & 1.92746 & 1.90436 & $\mathrm{~N} 1-\mathrm{Co}-\mathrm{C} 7$ & $87.5(1)$ & 87.32442 & 87.02476 \\
\hline & $\mathrm{N} 5{ }^{\prime}-\mathrm{Co}$ & $1.883(2)$ & 1.92662 & 1.90532 & $\mathrm{~N} 5-\mathrm{Co}-\mathrm{C} 7$ & $89.6(1)$ & 91.12499 & 87.44907 \\
\hline & $\mathrm{C} 7-\mathrm{Co}$ & $1.997(4)$ & 1.99551 & 1.97118 & $\mathrm{~N} 8-\mathrm{Co}-\mathrm{N} 1$ & $92.5(1)$ & 91.23058 & 91.11915 \\
\hline & N8-Co & $2.053(4)$ & 2.12165 & 2.07341 & $\mathrm{~N} 8-\mathrm{Co}-\mathrm{N} 5$ & $90.4(1)$ & 90.07403 & 91.20453 \\
\hline & $\mathrm{C} 3-\mathrm{N} 1$ & $1.291(4)$ & 1.30057 & 1.29548 & $\mathrm{~N} 8-\mathrm{Co}-\mathrm{C} 7$ & 180.0 & 177.96027 & 177.74887 \\
\hline & $\mathrm{C} 3^{\prime}-\mathrm{N} 1^{\prime}$ & $1.291(4)$ & 1.30020 & 1.29578 & & & & \\
\hline & $\mathrm{C} 4-\mathrm{N} 5$ & $1.304(4)$ & 1.31823 & 1.31140 & & & & \\
\hline & $\mathrm{C} 4^{\prime}-\mathrm{N} 5^{\prime}$ & $1.304(4)$ & 1.31837 & 1.31130 & & & & \\
\hline & $\begin{array}{r}R^{2} \\
R M S E \\
\end{array}$ & & $\begin{array}{r}0.9969 \\
0.034147 \\
\end{array}$ & $\begin{array}{r}0.99806 \\
0.016211 \\
\end{array}$ & $\begin{array}{r}R^{2} \\
R M S E \\
\end{array}$ & & $\begin{array}{r}0.99922 \\
1.099312 \\
\end{array}$ & $\begin{array}{r}0.99900 \\
1.398769 \\
\end{array}$ \\
\hline
\end{tabular}



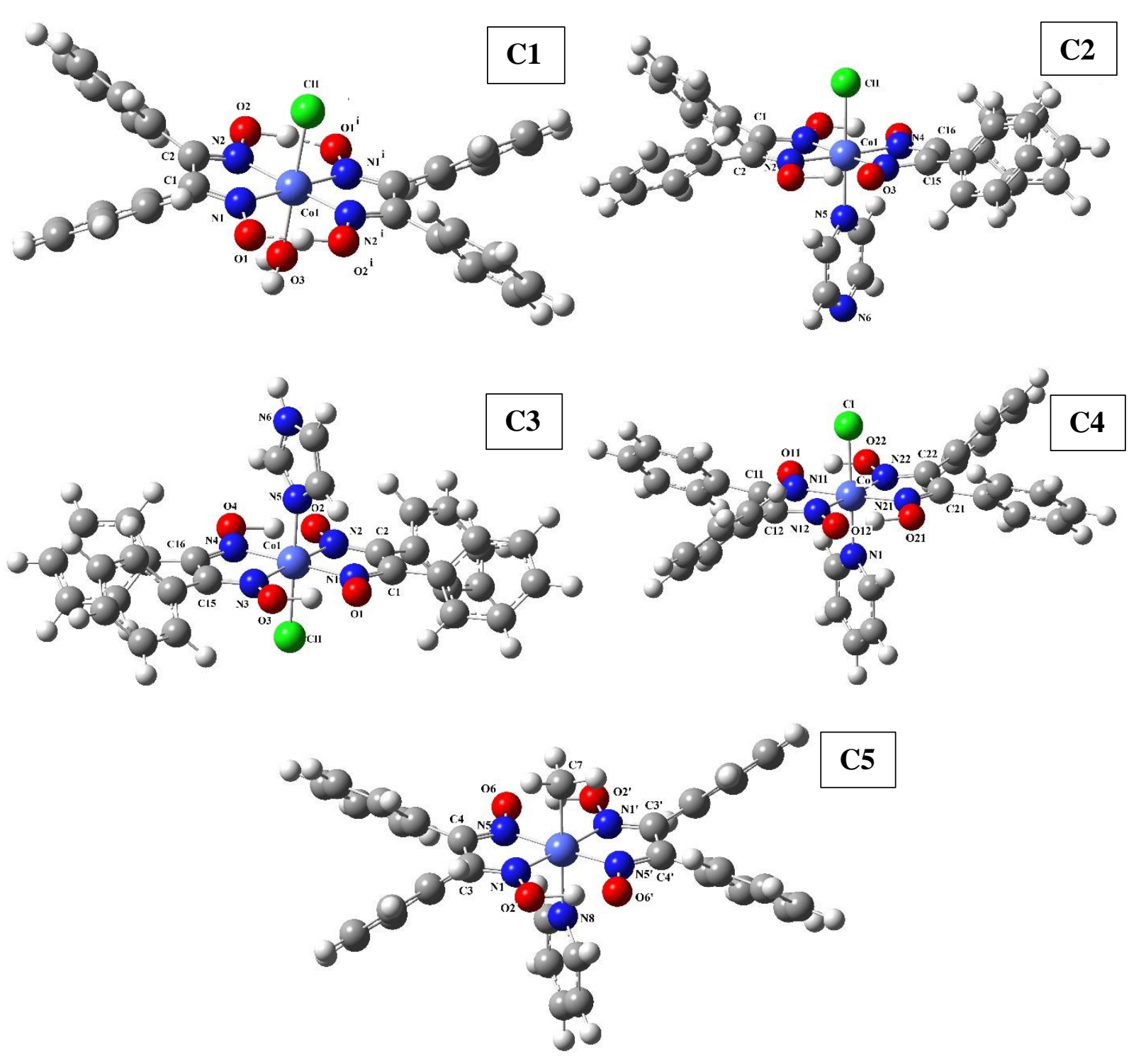

Figure 2. The optimized structures of complexes using the DFT/mPW1PW91 method

HOMO and LUMO are the highly significant orbitals that take part in the chemical reaction. The HOMO is the orbital that primarily acts as an electron donor, and the LUMO largely acts as the electron acceptor. The high HOMO energy corresponds to the more reactive molecule in the reactions with electrophiles, while the low LUMO energy corresponds to the molecular nucleophiles (Ekennia et al., 2015; Choudhary et al., 2019; Shukla et al., 2020). As seen from Figure 3, the energy values for both HOMO and LUMO of all the complexes are very close to each other. It can be said that these complexes have the same tendency to donate or accept an electron. The difference between the HOMO and LUMO energy values gives the HOMO-LUMO energy gap $\left(\Delta E_{\text {gap }}\right)$, which describes the chemical reactivity and kinetic stability of the molecules. The greater the $\Delta E_{\text {gap }}$ value, the more stable the molecule is and the lower its chemical reactivity (El- 
Gammal et al., 2019; Choudhary et al., 2019). All the Co-oxime complexes showed similar energy gaps, but the $\mathrm{C} 3, \mathrm{C} 4$ and $\mathrm{C} 5$ complexes with a greater $\Delta E_{\text {gap }}$ value were kinetically slightly more stable than the $\mathrm{C} 1$ and $\mathrm{C} 2$ complexes.

For all the complexes, the patterns of the occupied orbitals (HOMOs) were qualitatively similar. The HOMOs were mainly delocalized on the oxime groups of dpgh ligands and partly on the phenyl rings of this ligand (Figure 4). The contribution of axial position ligands to this orbital is zero in $\mathrm{C} 1$ and approximately 1 to $2 \%$ ( $\mathrm{N}$-donor ligands) in other complexes. The unoccupied moleculer orbitals (LUMOs) are mixed orbitals. In $\mathrm{C} 1$, the charge distribution of the LUMO lies principally on the dpgh ligands and Co cation. The LUMOs of C3 to C5 were very similar to their HOMOs and localized predominantly on dpgh ligands. The contributions of ligands at the axial position of the LUMOs were slightly higher than their contributions to HOMOs. Unlike the others, the LUMO of C2 was localized predominantly on the $\mathrm{Pz}$ ring coordinated at the axial position.

In light of all the results mentioned above, the oxime group of the dpgh ligand on which the HOMO is predominantly localized in all the cobaloxime complexes were considered to be more reactive towards electrophiles. Similarly, as an electrophile, the oxime group on which the LUMO was localized can prefer to interact with nucleophiles, except for the $\mathrm{C} 1$ and $\mathrm{C} 2$ complexes. In $\mathrm{C} 1$, the cobalt cation with the dpgh ligand may be preferred, while the $\mathrm{Pz}$ group in $\mathrm{C} 2$ is suitable for nucleophilic

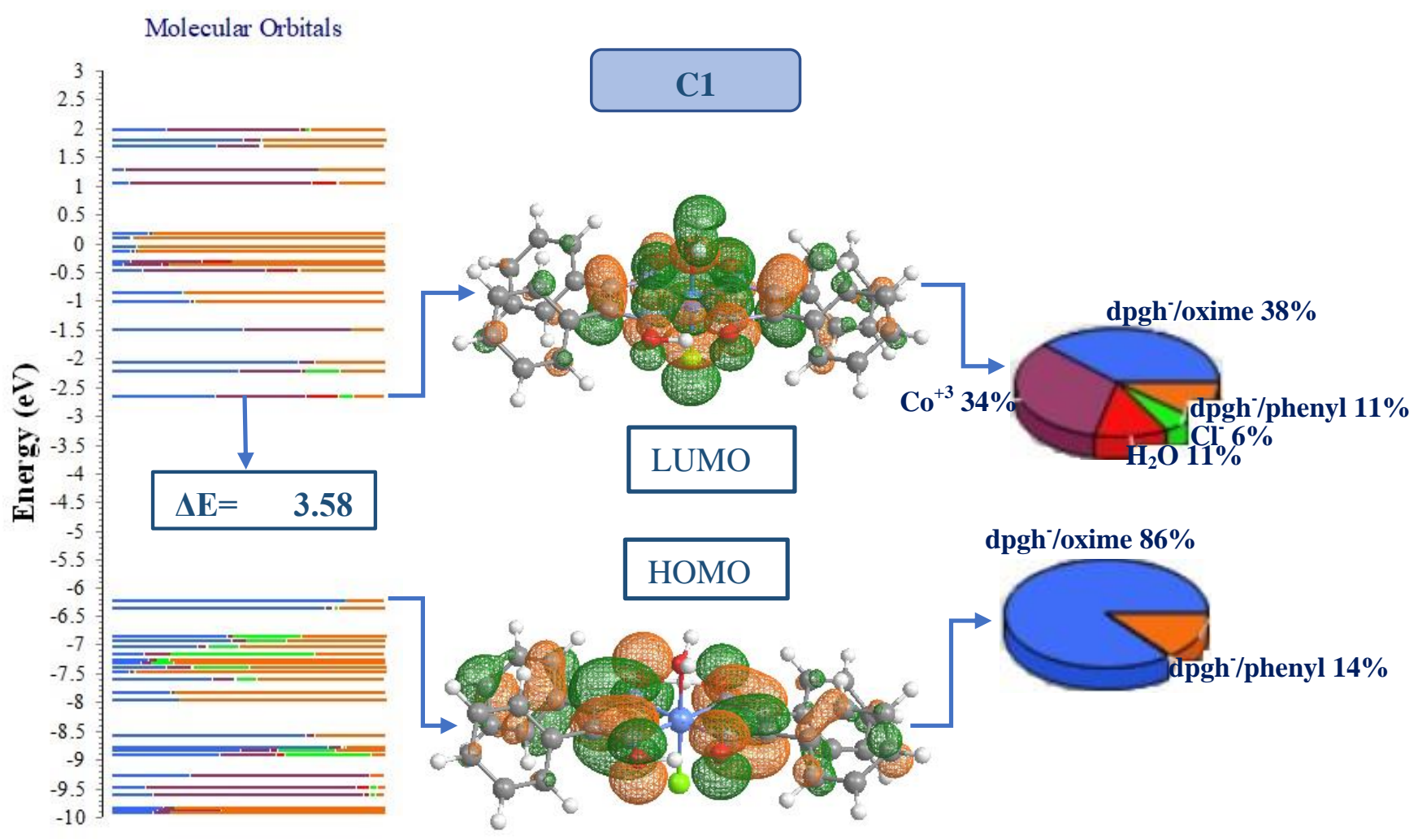



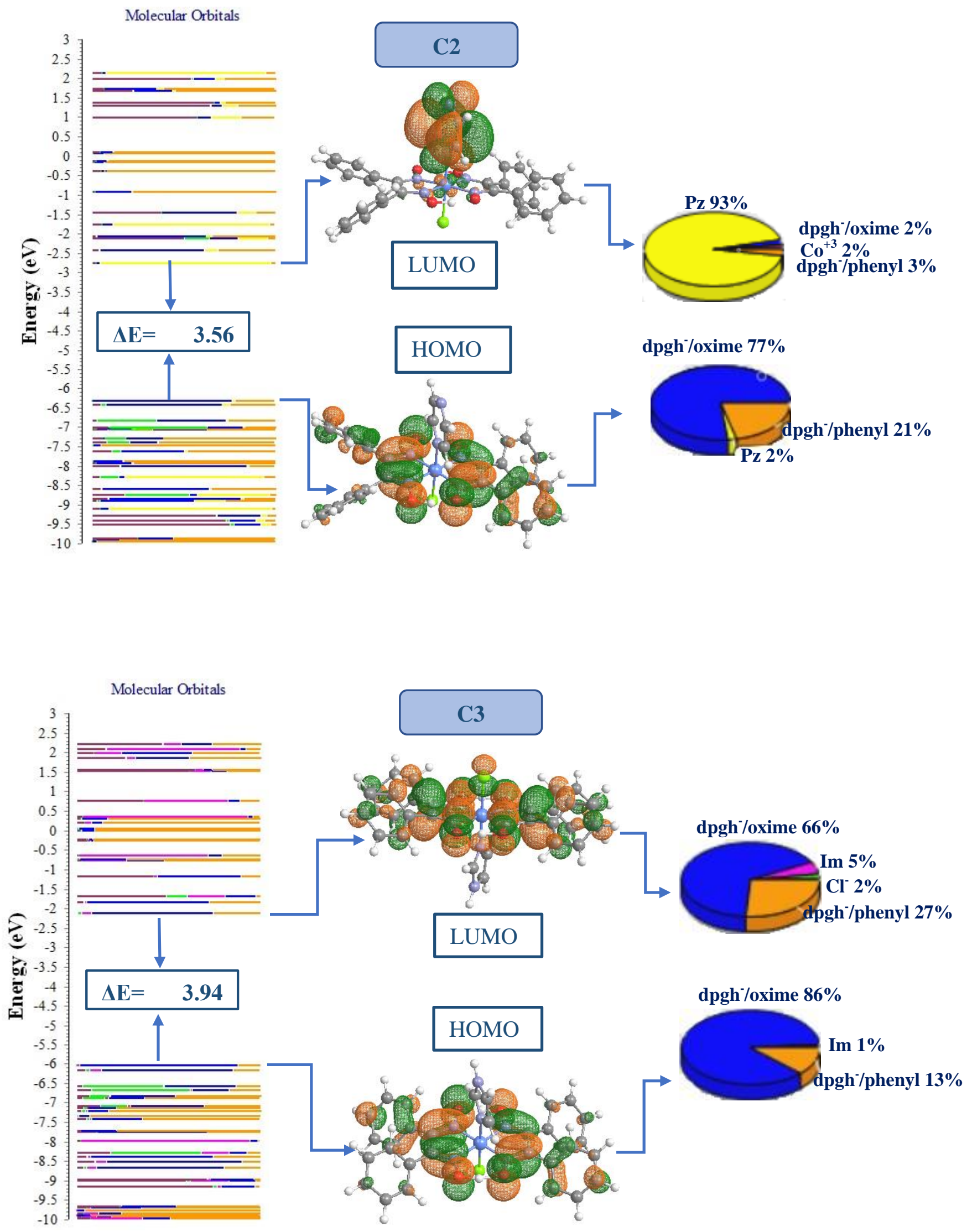

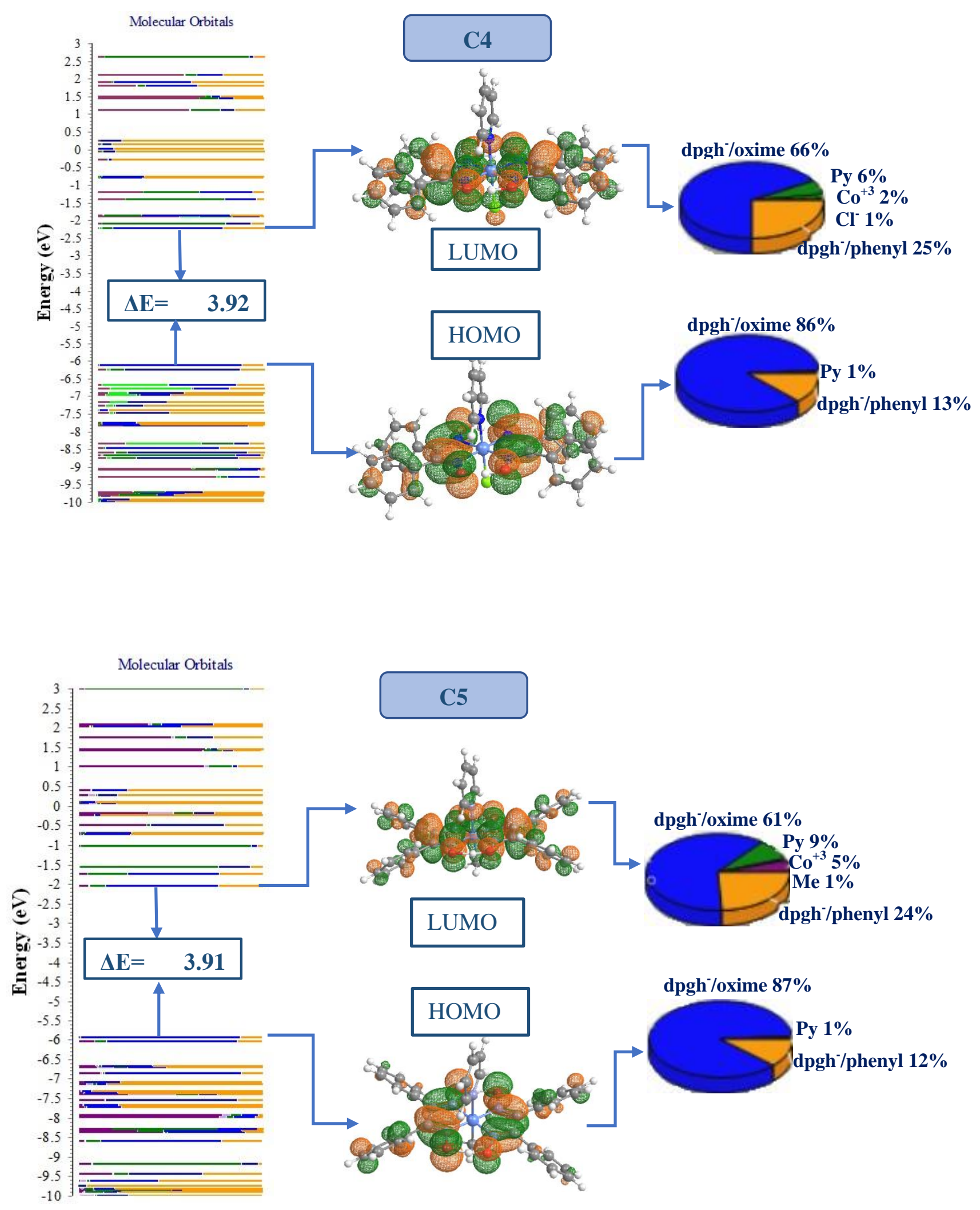

Figure 3. The molecular orbital energies, percentage distributions of the functional groups of cobaloxime complexes in the gaseous phase using the DFT/mPW1PW91 method 


\subsection{Global descriptors}

Reactivity descriptors based on density functional theory have been widely used in understanding the nature of chemical interactions and estimating the chemical reactivity of atoms, ions or molecules (Parthasarathi et al., 2003; Choudhary et al., 2019; Khan et al., 2020). In this study, the global reactivity parameters, such as chemical potential $(\mu)$, hardness $(\eta)$, softness $(S)$, electronegativity $(\chi)$, and electrophilicity index $(\omega)$, were calculated using the DFT/mPW1PW91 method for Co-oxime complexes, are presented in Table 2.

The chemical potential $(\mu)$ and chemical hardness $(\eta)$ were calculated using the first vertical ionization potential $(I P)$ and the first vertical electron affinity (EA) (Parr and Yang, 1989; Geerlings et al., 2003; Sandoval-Yañez and Martínez-Araya, 2019).

$$
\begin{aligned}
& \mu=-\frac{(I P+E A)}{2} \\
& \eta=\frac{(I P-E A)}{2}
\end{aligned}
$$

The vertical ionization potential (IP) and vertical electron affinity $(E A)$ are given by the following equations:

$$
\begin{aligned}
I P & =E_{N-1}-E_{N} \\
E A & =E_{N}-E_{N+1}
\end{aligned}
$$

where $N, E_{N+1}, E_{N-1}$ are the calculated total energies for the neutral, cationi and anionic states, respectively.

The electronegativity ( $\chi$ ) (Parr et al., 1989) is the negative value of $\mu$, and defined as follows:

$$
\chi=\frac{(I P+E A)}{2}
$$

The global electrophilicity, as introduced by Parr et al. (Parr et al., 1989), can be defined as follows:

$$
\omega=\frac{\mu^{2}}{2 \eta} \quad 9
$$

The global softness $S$ (Yang and Parr, 1985; Geerlings and Proft, 2003) is defined as the inverse of the global hardness $\eta$, and this quantity is given as follows:

$$
S=\frac{1}{2 \eta} \quad 10
$$

The chemical potential $(\mu)$ is the tendency of electrons to leave a stable system, and negative chemical potential indicates that it is a stable complex that does not decompose spontaneously into its elements (Choudhary et al., 2019). As can be seen from Table 2, all the complexes have negative chemical potential value, which are indicative of their stability suggesting that they do not undergo decomposition into their elements. These results are also in agreement with the thermodynamic results. The hardness parameter is a global property that is regarded as resistance to change in the electron distribution in the system, whereas global softness $(S)$ is associated with high polarizability. The soft molecules with a large $S$ value and small energy gap are more polarized and reactive than hard ones with a large $\eta$ value and large energy gap (Parr and Pearson, 1983; Geerlings et al., 2003; Choudhary et al., 2019). From Table 2, it is clear that among the complexes studied, the C3, C4 and C5 have the higher chemical hardness value of $\eta \approx 3 \mathrm{eV}$, and are more stable complexes than $\mathrm{C} 1$ and $\mathrm{C} 2$. The $\mathrm{C} 1$ has the highest softness value $(0.20 \mathrm{eV})$, and is chemically more reactive. These results are supported by the HOMO-LUMO gap. 
In quantum chemical studies, the electrophilicity index $(\omega)$ is a very important parameter that acts as a measure of energy lowering due to high electron transfer between donor and acceptor. It plays an important role in the analysis of the chemical reactivity of molecules (Ibrahim et al., 2014; Hepokur et al., 2017). Moreover, the reactivity of molecules, their site selectivity and degree of drug receptor interaction can be predicted with this parameter (Choudhary et al., 2019). The electrophilicity index $\omega$ value is related to chemical potential and hardness that are indicative of nucleophilic power. The calculated $\omega$ values indicated that the C1 complex had the highest electrophilicity index value $(4.36 \mathrm{eV})$ and was electrophilic in nature, while the remaining sequence of complexes was $\mathrm{C} 2>$ $\mathrm{C} 4$

C3 >

C5.

Table 2. Values of the global reactivity descriptors of the cobaloxime complexes calculated in the gaseous phase at the DFT/mPW1PW91/LANL2DZ level

\begin{tabular}{clllllll}
\hline Complex & $\mathbf{I . P}(\mathbf{e V})$ & $\mathbf{E . A}(\mathbf{e V})$ & $\boldsymbol{\mu}(\mathbf{e V})$ & $\boldsymbol{\eta}(\mathbf{e V})$ & $\chi(\mathbf{e V})$ & $\boldsymbol{\omega}(\mathbf{e V})$ & $\boldsymbol{S}\left(\mathbf{e V}^{-\mathbf{1}}\right)$ \\
\hline $\mathbf{C 1}$ & 7.45 & 2.16 & -4.8 & 2.64 & 4.80 & 4.36 & 0.19 \\
\hline $\mathbf{C 2}$ & 7.48 & 1.91 & -4.69 & 2.78 & 4.69 & 3.93 & 0.18 \\
\hline $\mathbf{C 3}$ & 7.24 & 1.07 & -4.16 & 3.08 & 4.16 & 2.80 & 0.16 \\
\hline $\mathbf{C 4}$ & 7.31 & 1.19 & -4.25 & 3.06 & 4.25 & 2.95 & 0.16 \\
\hline $\mathbf{C 5}$ & 7.08 & 1.04 & -4.06 & 3.02 & 4.06 & 2.73 & 0.17 \\
\hline
\end{tabular}

\subsection{Interaction of the cobaloxime complexes with DNA bases}

Stabilization energy and its components are derived on the basis of reactivity descriptors within the framework of DFRT (Sarmah and Roy, 2013; Sarmah and Roy, 2014). The expression of stabilization energy, which was developed by Parr and Pearson and reexpressed by Roy and collaborators is very handy to explain the most favorable interaction between two chemical systems, such as the interaction between drugs and their target (Sarmah and Roy, 2013; Sarmah and Roy, 2014).

The stabilization energy $\left(\triangle E_{S E(A B)}\right)$ (Sarmah and Roy, 2013; Sarmah and Roy, 2014), can be written as follows:

$\Delta E_{S E(A B)}=\Delta E_{A(B)}+\Delta E_{B(A)}=-\frac{\left(\mu_{B}^{0}-\mu_{A}^{0}\right)^{2}}{2\left(\eta_{A}+\eta_{B}\right)} 11$
The corresponding expression for the electron transfer $(\Delta \mathrm{N})$ (Sarmah and Roy, 2013) is:

$$
\Delta N=-\frac{\mu_{B}^{0}-\mu_{A}^{0}}{\left(\eta_{A}+\eta_{B}\right)} 12
$$

Where $\mu_{A}^{o}$ and $\eta_{A}^{o}$ are the chemical potential and hardness, respectively, for acceptor A. The symbols $\mu_{B}^{o}$ and $\eta_{B}^{o}$ describe the same descriptors for donor B. If $\mu_{B}^{o}>\mu_{A}^{o}$ (i.e. $\chi_{A}>$ $\left.\chi_{A B}\right), A$ is an acceptor and electrons flow from $B$ to $A$ in the formation of $A B$ (Sarmah and Roy, 2013; Sarmah and Roy, 2014).

In equation 11, the expression of the two individual components of stabilization energy (i.e., $\Delta E_{B(A)}, \Delta E_{A(B)}$ ) can be represented as follows:

$\Delta E_{B(A)}=\frac{\mu_{B}^{0}-\mu_{A}^{0}}{\left(\eta_{A}+\eta_{B}\right)}\left[-\mu_{B}^{0}+\frac{1}{2} \eta_{B}\left(\frac{\mu_{B}^{0}-\mu_{A}^{0}}{\left(\eta_{A}+\eta_{B}\right)}\right)\right] 13$ 


$$
\Delta E_{A(B)}=\frac{\mu_{B}^{0}-\mu_{A}^{0}}{\left(\eta_{A}+\eta_{B}\right)}\left[-\mu_{A}^{0}+\frac{1}{2} \eta_{A}\left(\frac{\mu_{B}^{0}-\mu_{A}^{0}}{\left(\eta_{A}+\eta_{B}\right)}\right)\right] 14
$$

$\Delta E_{B(A)}$ and $\Delta E_{A(B)}$ are changes in the energy of $\mathrm{B}$ and $\mathrm{A}$ during the process of chemical interaction between a donor (B) and acceptor (A). $\Delta E_{B(A)}$ is the energy raising component (i.e. positive quantity) and can be correleted to the kinetics or rate of a reaction or interaction, while $\Delta E_{A(B)}$ is the energy lowering component (i.e. negative quantity) and can be correleted to the thermodynamics or stability of the resultant adduct or product. The stabilization energy $\left(\Delta E_{S E(A B)}\right)$ is used to predict the thermodynamic stability of the resultant adduct. If the charge transfer process between the two interacting species occurs spontaneously, the $\Delta E_{S E(A B)}$ value will be a negative quantity. The higher the positive value of $\Delta E_{B(A)}$, the higher the rate of interaction will be between interacting species - that is, the interaction speed. The large negative values of $\Delta E_{A(B)}$ and $\Delta E_{S E(A B)}$ for a particular interacting pair indicate higher stability of the resulting adduct. The electron transfer value $(\Delta \mathrm{N})$ depends upon all the kinetic and thermodynamics descriptors. Therefore, both the rate of interaction and the stability of the adducts can be explained using $\Delta \mathrm{N}$ values. If an electron moves from the donor (B) to the acceptor (A), the $\Delta \mathrm{N}$ value will be positive (Sarmah and Roy, 2013; Sarmah and Roy, 2014).

The adenine (A), guanine $(\mathrm{G})$, cytosine $(\mathrm{C})$ and thymine $(\mathrm{T})$ bases that create DNA have $\mathrm{N}$ and/or $\mathrm{O}$ donor atoms. The uracil (U) which RNA contains is also considered as a mutagenic base in the DNA sequence. In this study, interactions of cobaloxime complexes with DNA bases and Watson-Crick base pairs (A-T and $\mathrm{G}-\mathrm{C}$ ) were theoretically investigated by the above said reactivity parameters (i.e., $\Delta E_{B(A)}, \Delta E_{A(B)}, \Delta E_{S E(A B)}$ and $\Delta \mathrm{N})$. These descriptors were calculated using
Equations 11 to 14, and the results are listed in Table 3. Based on the values in the table and the explanations above, it can be said that the complexes and DNA bases commonly act as acceptor and donor, respectively, in the interaction of the studied cobaloxime complexes with DNA bases. From the values of $\Delta E_{B(A)}$, it can be concluded that for cobaloxime complexes, the preferred active site for interaction in DNA is the guanine base. The rate of interaction of nucleobases with complexes, as per the data in Table 3, follows the sequence $\mathrm{G}>\mathrm{A}>\mathrm{C}>\mathrm{T}>\mathrm{U}$. According to $\Delta E_{B(A)}$ values, the interaction between the $\mathrm{G}$ $\mathrm{C}$ base pair and cobaloxime complexes is faster than that between the $\mathrm{A}-\mathrm{T}$ base pair and complexes. The values of $\Delta E_{A(B)}$ and $\triangle E_{S E(A B)}$ predicted the same trend as the $\Delta E_{B(A)}$ observations, that is, the adduct formation between the guanine base and the complexes was thermodynamically more favorable than with the other bases. These values for guanine-complex adducts, were more negative than those generated for other base-complex adducts. The values of $\Delta \mathrm{N}$ supported the results based on the $\Delta E_{B(A)}$, $\Delta E_{A(B)}$ and $\Delta E_{S E(A B)}$ values. For all cobaloxime complexes, the largest positive values for $\Delta \mathrm{N}$ belonged to the cobaloxime complexes-guanine base interactions, and these interactions were both kinetically and thermodynamically more preferable according to the other interactions. In the case of interaction of $\mathrm{C} 3$ with uracil, and $\mathrm{C} 5$ with thymine and uracil, the values of $\Delta E_{B(A)}$ and $\Delta \mathrm{N}$ were found to be negative, while the values of $\Delta E_{A(B)}$ and $\Delta E_{S E(A B)}$ were positive. These results indicated that the direction of charge transfer was from these complexes to the thymine and uracil bases. Moreover, the values in Table 3 clearly showed that the fastest interaction and the formation of the most stable adducts were between all DNA 
bases and the $\mathrm{C} 1$ complex which has $\mathrm{Cl}$ and $\mathrm{H}_{2} \mathrm{O}$ ligands in the axial position.

Table 3. $\Delta N, \Delta E_{B(A)}, \Delta E_{A(B)}$ and $\Delta E_{S E(A B)}$ values of interaction of cobaloxime complexes with DNA bases and the WatsonCrick base pairs at the DFT/mPW1PW91/LANL2DZ level

\begin{tabular}{|c|c|c|c|c|}
\hline & $\Delta N$ & $\Delta E_{B(A)}$ & $\Delta E_{A(B)}$ & $\Delta E_{S E(A B)}$ \\
\hline \multicolumn{5}{|c|}{ Adenine } \\
\hline C1 & 4.39 & 16.98 & -19.97 & -2.99 \\
\hline $\mathrm{C} 2$ & 3.96 & 15.14 & -17.62 & -2.48 \\
\hline $\mathrm{C3}$ & 2.19 & 8.00 & -8.79 & -0.79 \\
\hline $\mathrm{C4}$ & 2.47 & 9.09 & -10.10 & -1.00 \\
\hline C5 & 1.90 & 6.89 & -7.49 & -0.59 \\
\hline \multicolumn{5}{|c|}{ Guanine } \\
\hline C1 & 4.86 & 18.50 & -21.96 & -3.46 \\
\hline $\mathrm{C} 2$ & 4.39 & 16.55 & -19.43 & -2.89 \\
\hline $\mathrm{C3}$ & 2.51 & 9.04 & -10.03 & -0.98 \\
\hline C4 & 2.81 & 10.18 & -11.41 & -1.23 \\
\hline C5 & 2.21 & 7.89 & -8.65 & -0.76 \\
\hline \multicolumn{5}{|c|}{ Cytosine } \\
\hline C1 & 2.73 & 11.52 & -12.67 & -1.15 \\
\hline $\mathrm{C} 2$ & 2.33 & 9.73 & -10.59 & -0.85 \\
\hline $\mathrm{C3}$ & 0.62 & 2.49 & -2.55 & -0.06 \\
\hline $\mathrm{C4}$ & 0.90 & 3.63 & -3.76 & -0.13 \\
\hline C5 & 0.32 & 1.27 & -1.28 & -0.02 \\
\hline \multicolumn{5}{|c|}{ Thymine } \\
\hline $\mathrm{C1}$ & 2.20 & 9.54 & -10.30 & -0.76 \\
\hline $\mathrm{C} 2$ & 1.82 & 7.79 & -8.32 & -0.52 \\
\hline $\mathrm{C3}$ & 0.14 & 0.59 & -0.60 & 0.00 \\
\hline $\mathrm{C} 4$ & 0.42 & 1.73 & -1.76 & -0.03 \\
\hline C5 & -0.16 & -0.65 & 0.65 & 0.00 \\
\hline \multicolumn{5}{|c|}{ Uracil } \\
\hline C1 & 1.91 & 8.36 & -8.96 & -0.60 \\
\hline $\mathrm{C} 2$ & 1.55 & 6.71 & -7.11 & -0.40 \\
\hline $\mathrm{C3}$ & -0.03 & -0.12 & 0.12 & 0.00 \\
\hline $\mathrm{C} 4$ & 0.23 & 0.96 & -0.97 & -0.01 \\
\hline C5 & -0.32 & -1.32 & 1.30 & -0.02 \\
\hline \multicolumn{5}{|c|}{$A-T$} \\
\hline $\mathrm{C1}$ & 4.02 & 16.09 & -18.38 & -2.30 \\
\hline $\mathrm{C} 2$ & 3.56 & 14.09 & -15.93 & -1.84 \\
\hline $\mathrm{C3}$ & 1.66 & 6.30 & -6.71 & -0.42 \\
\hline $\mathrm{C} 4$ & 1.96 & 7.50 & -8.08 & -0.58 \\
\hline C5 & 1.34 & 5.05 & -5.32 & -0.27 \\
\hline \multicolumn{5}{|c|}{$G-C$} \\
\hline $\mathrm{C1}$ & 5.38 & 20.41 & -24.15 & -3.73 \\
\hline $\mathrm{C} 2$ & 4.84 & 18.18 & -21.27 & -3.09 \\
\hline
\end{tabular}

\begin{tabular}{lllll} 
C3 & 2.70 & 9.73 & -10.74 & -1.01 \\
C4 & 3.03 & 11.01 & -12.28 & -1.27 \\
C5 & 2.36 & 8.45 & -9.22 & -0.77 \\
\hline
\end{tabular}

\section{Conclusions}

In this study, the molecular properties of some cobaloxime complexes were investigated using the DFT. The bond lengths and angles were calculated using B3LYP and mPW1PW91 and found to be in good agreement with that obtained by X-ray diffraction. The molecular properties of the structures, such as chemical potential $(\mu)$, hardness $(\eta)$, softness $(S)$, electronegativity $(\chi)$ and the electrophilicity index $(\omega)$, were investigated by means of computational studies. The results indicated that $\mathrm{C} 1$ was electrophilic in nature, and had the highest tendency to accept electrons from the appropriate occupied orbitals of an electrondonating species. The interactions between cobaloxime complexes and DNA bases were investigated using values of $\Delta E_{B(A)}, \Delta E_{A(B)}$, $\Delta E_{S E(A B)}$ and $\Delta \mathrm{N}$ reactivity descriptors. Generally, it was observed that the complexes can act as acceptors toward DNA bases. The calculated values of descriptor parameters proved that the cobaloxime complexes investigated in this study interacted more effectively with the guanine base than with other nucleobases. Of the Watson-Crick base pairs, the $\mathrm{G}-\mathrm{C}$ pair interacted more effectively with the complexes than the A-T pair. Uracil, a mutagenic base, exhibited the least interaction with all DNA bases chosen in this study. Also $\mathrm{C} 1$ with inorganic ligands $\left(\mathrm{H}_{2} \mathrm{O}\right.$ and $\mathrm{Cl}^{-}$) in the axial position was found to form more stable adducts and showed a higher rate of interaction with all nucleobases than other complexes with organic ligands in the axial position. According to the FMOs analyses results, it can be said that the 
interaction of the $\mathrm{C} 1$ complex with DNA bases may occur between the Co cation and the dpgh ligands on which LUMO was delocalized, and with nitrogen and/or oxygen atoms with lone pairs of electrons in biomolecules. It is hoped that this study will be helpful to predict the reactivity of cobaloxime complexes in the presence of nucleobases, and for the design of new cobaloxime complexes that can exhibit drug agent properties.

\section{References}

Adamo, C., Barone, V. 1998. "Exchange functionals with improved long-range behavior and adiabatic connection methods without adjustable parameters: The $\mathrm{mPW}$ and mPW1PW models", J. Chem. Phys., 108, 664-675.

Bagaria, P., Saha, S., Murru, S., Kavala, V., Patel, B.K. and Roy, R. K. 2009. "A comprehensive decomposition analysis of stabilization energy (CDASE) and its application in locating the rate-determining step of multi-step reactions", Phys. Chem. Chem. Phys., 11, 8306-8315.

Becke, A. D. 1992. "Density-functional thermochemistry. II. The effect of the Perdew-Wang generalized-gradient correlation correction", J. Chem. Phys., 97, 9173-9177.

Becke, A. D. 1993. "Density-functional thermochemistry. III. The role of exact Exchange", J. Chem. Phys., 98(7), 56485652.

Bhattacharjee, A., Andreiadis, E. S., Chavarot-Kerlidou, M., Fontecave, M., Field, M. J., Artero, V. A. 2013. "Computational Study of the Mechanism of Hydrogen
Evolution by Cobalt (Diimine-Dioxime)" Catalysts. Chem. - Eur. J., 19, 15166-1517.

Bhuyan, M., Laskar, M., Gupta, B. D. 2008. "Biphenyl-Bridged Dicobaloximes: Synthesis, NMR, CV, and X-Ray Study", Organometallics, 27, 594-601.

Bourosh, P. N., Coropceanu, E. B., Ciloci, A. A., Clapco, S. F., Bologa, O. A., Bivol, C. M., Tiurina, J. P., Bulhac, I. 2013. "New Co(III) Dioximates with Hexafluorophosphate Ion as Stimulators of the Proteolytic Activity of the Micromycete Fusarium gibbosum CNMN FD 12", Russ. J. Coord. Chem., 39(11), 777-786.

Chen. J., Sit, P. H. L. 2018. "Ab initio study of ligand dissociation/exchange and the hydrogen production process of the $\mathrm{Co}(\mathrm{dmgH}) 2(\mathrm{py}) \mathrm{Cl}$ cobaloxime in the acetonitrile-water solvent", Catalysis Today, 314, 179-186.

Choudhary,V. K., Bhatt, A. K., Dash, D., Sharma, N. 2019. "DFT Calculations on Molecular Structures, HOMO-LUMO Study, Reactivity Descriptors and Spectral Analyses of Newly Synthesized Diorganotin(IV) 2Chloridophenylacetohydroxamate Complexes" J. Comput. Chem., 40, 23542363.

Coropceanua E. B., Rijaa, A. P., Lozana, V. I., Bologaa, O. A., Boldisora, A. A., Bulhaca, I. I., Ch. Kravtsovb, V., Bouroshb, P. N. 2012. "Synthesis and Crystal Structure of Co(III) Dioximates with the Complex Anion [SbF6]" Russ. J. Coord. Chem., 38(8), 545551.

Coropceanua, E. B., Bulhaca, I., Shtefyrtseb, A. A., Botnar'b, V. F., Melenchukb, M., Kuligina, E., Bouroshc, P. N. 2017. "Synthesis, Crystal Structure, and Biological 
Properties of the Complex [Co(DmgH)2(Seu)1.4(Se-

Seu)0.5(Se2)0.1][BF4]" Russ. J. Coord. Chem., 43(3), 164-171.

Dennington, R., Keith, T., Millam, J., GaussView, Version 5, Semichem Inc., Shawnee Mission KS, 2009.

Ekennia, A. C., Onwudiwe, D. C, Olasunkanmi, L. O., Osowole, A. A., Ebenso, E. E. 2015. "Synthesis, DFT Calculation, and Antimicrobial Studies of Novel $\mathrm{Zn}(\mathrm{II}), \mathrm{Co}(\mathrm{II}), \mathrm{Cu}(\mathrm{II})$, and $\mathrm{Mn}$ (II) Heteroleptic Complexes Containing Benzoylacetone and Dithiocarbamate" Hindawi Publishing Corporation Bioinorg. Chem. Appl., Article ID 789063, 12 pages.

El- Gammal, O. A., Abu El- Reash, G. M., Bedier, R. A. 2019. "Synthesis, spectroscopic, DFT, biological studies and molecular docking of oxovanadium (IV), copper (II) and iron (III) complexes of a new hydrazone derived from heterocyclic hydrazide" Appl. Organometal Chem., 33, e5141.

Frau, J., Muñoz, F., Glossman-Mitnik, D. 2017, "A Conceptual DFT Study of The Chemical Reactivity of Magnesium Octaethylporphyrin (Mgoep) as Predicted by The Minnesota Family of Density Functionals" Quim DGM. Nova, 40(4), 402406.

Frisch, M. J, Trucks, G. W., Schlegel, H. B., Scuseria, G. E., Frisch, H., Trucks, M. J., Schlegel, G. W., Scuseria, H. B, Robb, G. E., Cheeseman, M. A., Scalmani, J. R., Barone, G., et al. 2017. Gaussian 09. Revision E01 edn. Gaussian Inc, Wallingford, CT.

Gao, Y., Lin, H., Zhang, S., Li, Z. 2016. " $\mathrm{Co}(\mathrm{dmgH}) 2 \mathrm{pyCl}$ as a noble-metal-free co- catalyst for highly efficient photocatalytic hydrogen evolution over hexagonal $\mathrm{ZnIn}_{2} \mathrm{~S}_{4}$ ", RSC Adv., 6, 6072-6076.

Geerlings, P., Proft, F. D., Langenaeker, W. 2003. "Conceptual density functional theory" Chem. Rev., 103, 1793-1874.

Gupta, B. D., Yamuna, R., Mandal, D. 2006. "Cobaloximes with Mixed Dioximes of Glyoxime and Diphenylglyoxime: Synthesis, Characterization, CV, X-ray Studies, and Crystal Packing”, Organometallics, 25, 706714.

Hamid, A., Roy, R. K. 2019. "Solvent effect on stabilization energy: An approach based on density functional reactivity theory", Int $J$ Quantum Chem, 119, e25909.

Hamid, A., Roy, R. K. 2020. "Correlation between Equilibrium Constant and Stabilization Energy: A Combined Approach Based on Chemical Thermodynamics, Statistical Thermodynamics, and Density Functional Reactivity Theory", J. Phys. Chem. A, 124, 1279-1288.

Hepokur, C., Günsel, A., Yarasir, M. N., Bilgiçli, A. T., Tüzün, B., Tüzün, G., Yaylim, İ. 2017. "Novel type ketonesubstituted metallophthalocyanines: synthesis, spectral, structural, computational and anticancer studies", RSC Adv., 7, 5629656305.

Ibrahim, K. M., Zaky, R. R., Abou-El-Nadar, H. M., Abo-Zeid, S. M. 2014. "Structural, spectral, DFT and biological studies of (E)-3(2-(2-hydroxybenzylidene)hydrazinyl)- 3oxo-N-(p-tolyl)propanamide complexes", $J$. Mol. Struct., 1075, 71-84.

Jiang, Y. K., Liu, J. H. 2012. "DFT Studies of Cobalt Hydride Intermediate on 
Cobaloxime-Catalyzed $\quad \mathrm{H}_{2} \quad$ Evolution Pathways", Int. J. Quantum Chem., 112, 2541-2546.

Khan, S. A., Rizwan, K., Shahid, S., Noamaan, M. A., Rasheed, T., Amjad, H. 2020. "Synthesis, DFT, computational exploration of chemical reactivity, molecular docking studies of novel formazan metal complexes and their biological applications", Appl Organometal Chem., e5444, 1-24.

Krishnan, R., Frisch, M. J., Pople, J. A. J. 1980. "Contribution of triple substitutions to the electron correlation energy in fourth order perturbation theory", Chem. Phys., 72(7), 4244-4245.

Kumar, K., Kumar, S., Gupta, B. D. 2010. "Weak interactions between furfuryl and equatorial dioxime ligand in furfuryl $(\mathrm{O} 2) \mathrm{Co}(\mathrm{dmgH}) 2 \mathrm{Py}$ : NMR, X-ray and DFT calculations", J Organomet Chem., 695, 512-517.

Kumar, K., Gupta, B. D. 2010. "Synthesis, characterization, $\mathrm{CV}$, and $\mathrm{X}$-ray structures of aryl cobaloximes", J Organomet Chem., 695, 2233-2239.

Kurnaz, P., Yuksektepe, Ataol, C., Bati, H., Buyukgungor, O. 2016. "XRD, FTIR, ${ }^{1} \mathrm{H}$ NMR, ${ }^{13} \mathrm{C}$ NMR and UV spectroscopic and computational studies of [3(hydroxyimino)butan-2-ylidene]furan-2'carbohydrazide", Mol. Cryst. Liq. Cryst., 634, 61-72.

Lee, C., Yang, W., Parr, R. G. 1988. "Development of the Colle-Salvetti correlationenergy formula into a functional of the electron density", Phys. Rev. B Condens. Matter, 37, 785-789.
Lopez, C., Alvarez, S., Aguiló, M., Solans, X., Font-Altaba, M. 1987. "Synthesis and Structure of Chloro(ligand)bis( diphenylglyoximato)cobalt( III) Complexes", Inorg. Chim. Acta, 127 (1987), 153-159.

Lopez, C., Alvarez, S., Font-Bardía, M., Solans, X. 1991. "New organometallic cobaloximes containing an equatorial diphenylglyoximato(-1) ligand. Comparison between their properties and those of other $\mathrm{B}_{12}$ model compounds. Crystal structure of trans-[Co( dpgH) 2( $\mathrm{CH}$, $)($ pyridine $)]$ ", $J$. Organomet. Chem., 414, 245-259.

Lynch, B. J., Fast, P. L., Harris, M., Truhlar, D. G. 2000. "Adiabatic Connection for Kinetics", J. Chem. Phys. A, 104, 4811-4815.

Mandal, D., Gupta, B. D. 2006. "Cobaloximes with Pyrazine and Their Dimetallic Complexes", Eur. J. Inorg. Chem., 4086-4095.

McCormick, T. M., Han, Z., Weinberg, D. J., Brennessel, W. W., Holland, P. L., Eisenberg, R. 2011. "Impact of Ligand Exchange in Hydrogen Production from Cobaloxime-Containing Photocatalytic Systems", Inorg. Chem., 50, 10660-10666.

Meera, P., Revathi, C., Dayalan, A. 2009. "Chloridobis[diphenylglyoximato(1-)-

$\left.k^{2} \mathrm{~N}, \mathrm{~N}^{3}\right](1 \mathrm{H}$-imidazole-jN3)cobalt(III) hemihydrate", Acta Cryst., E65, m140m141.

Meera, P., Selvi, M. A., Dayalan, A. 2011. "Aquachloridobis(diphenylglyoximatok ${ }^{2} \mathrm{~N}, \mathrm{~N}$ ')cobalt(III) dihydrate", Acta Cryst., E67, m626-m627.

Muckerman, J. T., Fujita, E. 2011. "Theoretical Studies of the Mechanism of Catalytic Hydrogen Production by a 
Cobaloxime", Chem. Commun., 47, 12456-12458.

Natali, M. 2017. "Elucidating the Key Role of $\mathrm{pH}$ on Light-Driven Hydrogen Evolution by a Molecular Cobalt Catalyst", ACS Catal., 7, 1330-1339.

Parr, R. G., Pearson, R. G. 1983. “Absolute hardness: companion parameter to absolute electronegativity", J. Am. Chem. Soc., 105, 7512-7516.

Parr, R., Yang, W. 1989. "DensityFunctional Theory of Atoms and Molecules", Oxford Univ. Press, New York.

Parr, R. G, Szentpaly, L. V., Liu, S. 1999. "Electrophilicity Index" J. Am. Chem. Soc., 121, 1922-1924.

Parthasarathi, R., Padmanabhan, J., Subramanian, V., Maiti, B., Chattaraj, P. K. 2003. "Chemical Reactivity Profiles of Two Selected Polychlorinated Biphenyls", $J$. Phys. Chem. A, 107, 10346-10352.

Saha, S., Roy, R. K., Pal, S. 2010. "CDASE-A reliable scheme to explain the reactivity sequence between Diels-Alder pairs", Phys. Chem. Chem. Phys., 12, 93289338.

Sandoval-Yañez, C., Martínez-Araya, J. I. 2019. "Assessment of a Set of Twelve Density Functionals to estimate the Global Reactivity of Myricetin through the Koopmans' Theorem", Chem. Phys. Lett., 715, 354-359.

Sarmah, A., Roy, R., K. 2013. "Understanding the preferential binding interaction of aqua-cisplatins with nucleobase guanine over adenine: a density functional reactivity theory based approach", RSC Adv., 3, 2822-2830.
Sarmah, A., Roy, R. K. 2014. "A density functional reactivity theory (DFRT) based approach to understand the interaction of cisplatin analogues with protecting agents", $J$ Comput Aided Mol Des, 28, 1153-1173.

Shukla, S. N., Gaur, P., Raidas, M. L., Chaurasia, B. 2020. "Tailored synthesis of unsymmetrical tetradentate ONNO schiff base complexes of $\mathrm{Fe}(\mathrm{III}), \mathrm{Co}(\mathrm{II})$ and $\mathrm{Ni}(\mathrm{II})$ : Spectroscopic characterization, DFT optimization, oxygen-binding study, antibacterial and anticorrosion activity", $J$. Mol. Struct., 1202, 127362.

Skripnikov, L. V., Chemissian Visualization Computer Program v4.43, www.chemissian.com, 2016.

Solis, B. H., Hammes-Schiffer, S. 2011. "Theoretical Analysis of Mechanistic Pathways for Hydrogen Evolution Catalyzed by Cobaloximes", Inorg. Chem., 50, 11252-11262.

Solis, B. H., Yu, Y., Hammes-Schiffer, S. 2013. "Effects of Ligand Modification and Protonation on Metal Oxime Hydrogen Evolution Electrocatalysts", Inorg. Chem., 52, 6994-6999.

Dunning Jr., T. H., Hay, P. J., Schaefer III (Ed.) H. F. (1976) "Modern Theoretical Chemistry, vol. 3", Plenum, New York, p. 1.

Xu, Y., Chen, R., Li, Z., Li, A., Han, H., Li, C. 2017. "Influence of the Electrostatic Interaction between a Molecular Catalyst and Semiconductor on Photocatalytic Hydrogen Evolution Activity in Cobaloxime/CdS Hybrid Systems", A.C.S. Appl, Mater. Inter., 9, 23230-23237.

Yang, Y., Gao, H. 2012. "Comparison of DFT methods for molecular structure and 
vibration spectra of ofloxacin calculations", Spectrochim. Acta A, 85, 303-309.

Yang, W., Parr, R. G. 1985. "Hardness, softness, and the fukui function in the electronic theory of metals and catalysis", Proc. Natl. Acad. Sci. USA, 82, 6723-6726.

Ye, Y., Xu, Y., Huang, L., Fan, D., Feng, Z., Wang, X., Li, C. 2016. "Roles of adsorption sites in electron transfer from $\mathrm{CdS}$ quantum dots to molecular catalyst cobaloxime studied by time-resolved spectroscopy, Phys. Chem. Chem. Phys., 18, 17389-17397.

Zhao, Y., Tishchenko, O., Truhlar, D. G. 2005. "How Well Can Density Functional Methods Describe Hydrogen Bonds to $\pi$ Acceptors?", J. Phys. Org. Chem. B 109, 19046-19051. 